\title{
Selected Reference Books of 1984-85
}

\section{Eugene P. Sheehy}

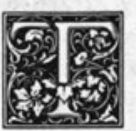

his article continues the semiannual series initiated by the late Constance M. Winchell more than thirty years ago. Although it appears under a byline, the list is a project of the reference departments of Columbia University's Butler and Lehman libraries, and notes are signed with the initials of the individual staff members. ${ }^{1}$

Since the purpose of the list is to present a selection of recent scholarly and general works of interest to reference workers in university libraries, it does not pretend to be either well balanced or comprehensive. A brief roundup of new editions of standard works is provided at the end of the article. Code numbers (such as AE213, CJ34) have been used to refer to titles in the Guide to Reference Books and its supplements. $^{2}$

\section{DICTIONARIES}

Dictionary of American Regional English. Frederic G. Cassidy, chief ed. Cambridge, Mass., Belknap, 1985-

V.1- . maps. (In progress) LC

84-29025. ISBN 0-674-20511-1.

Contents: V.1, Introduction; A-C (clvip., 903p.) $\$ 60$.

Not only is this a work of linguistic scholarship and the fruit of dedicated cooperative effort, it promises to be a treasure trove for browsers and lovers of words. Concentrating on colloquialisms, regional usages, dialect and ethnic terms, and out-of-the-way meanings, "DARE does not treat technical, scientific, or other learned words or phrases-or anything else that could be considered standard" (introduction). Vocabulary is derived mainly from responses to 1,847 questions in a carefully constructed questionnaire (reprinted in the introduction) administered by field workers in 1,002 communities throughout the United States. "The aim was to choose relatively stable communities distributed according to the states' composition, and communities of various types [i.e., urban, large city, small city, village, rural], so that the aggregate would reflect the makeup of each state's population." Additional terms were drawn from older works (published and unpublished) and from the files of the American Dialect Society, a long-time sponsor of the dictionary.

Entries (mainly under single words, but with many compounds and phrases) indicate parts of speech, variant spellings, etymologies for words not treated in standard dictionaries, geographical labels, usage labels, quotations with dates, and cross-references to related terms; treatment of pronunciation varies, and there is a lengthy "Guide to Pronunciation" (p.x1-1xi). Computer-generated maps (questionnaire responses were entered into a DARE database) accompany many entries; these maps indicate geographical distribution of usages and are "populational" rather than "areal," so that state shape and size are distorted to reflect pop-

1. Mary Cargill, Anita Lowry, Eileen Mcllvaine, Louise Sherby, Sarah Spurgin, Junko Stuveras; Lehman Library: Laura Binkowski, Diane Goon, Debi Hassig.

2. Eugene P. Sheehy, Guide to Reference Books, 9th ed. (Chicago: American Library Assn., 1976); first supplement (Chicago: American Library Assn., 1980); second supplement (Chicago: American Library Assn., 1982). 
ulation density. This first volume constitutes about one-quarter of the projected set. $-E . S$.

\section{PERIODICALS}

International Film, Radio and Television Journals. Ed. by Anthony Slide. Westport, Conn., Greenwood, [1985]. 428p. $\$ 49.95$. LC 84-8929. ISBN 0-31323759-X.

This bibliography is only nominally international in coverage; of its 189 entries, 122 are for American periodicals, 41 are for British, and only 26 are for publications from other countries. These twenty-six, including only four from France, hardly justify considering this an international bibliography, and the work must be recognized for what it is: a selective list of major, and some of the not-so-major, English-language periodicals, primarily in the field of film.

For each journal, a historical/critical essay provides an overview of its genesis, development, orientation, and purpose, along with brief evaluative remarks; typical articles and authors are frequently cited. The essay is followed by a list of information sources indicating where the journal is indexed, where reprint or microform editions are available, and which libraries own the journal (holdings are not indicated); the information provided is selective and not comprehensive. A quite detailed publication history, showing title changes, volume and issue data, publisher and place of publication, and editor for the entire history of the journal completes each entry. Citations to secondary literature are included for some of the better-known publications. Each entry is signed. Appendixes 1 through 4 consist of short bibliographic essays on fan-club journals, fan magazines, in-house journals, and national film journals. There are lists by country of publication, and by type and subject matter in appendixes 5 and 6 . A general bibliography and an index of names and titles also are included. - A.L.

Union List of Victorian Serials: A Union List of Selected Nineteenth-Century British Serials
Available in United States and Canadian Libraries. Gen. eds., Richard D. Fulton and C. M. Colee. N.Y., Garland, 1985. 732p. \$103. LC 84-45390. ISBN 0-8240-8846-8.

This finding aid is "based on the list of periodicals included in volume 3 of the New Cambridge Bibliography of English Literature, with about one-hundred titles added in science and technology"-Introduction. Approximately eighteen hundred serials and cross-references are listed in alphabetical order, with numerical references to The Waterloo Directory of Victorian Periodicals (Suppl. AE24) and the NCBEL (Suppl. BD83), bibliographic description and notes, and often shelf-checked holdings for each library surveyed. The list intends to include libraries with "major Victorian serials collections, and those that are the major scholarly resource for a given geographical area." But coverage is uneven. Fifty-nine Florida libraries, including several community colleges, are listed, yet major research libraries such as the Newberry Library, Boston Public Library, Dartmouth College, Princeton University, and the universities of Illinois, Indiana, and Wisconsin are not. Meant to "clear up bibliographic questions on many items . . . such as beginning dates, titles, and subtitle changes, inclusive series dates, and concluding dates," the work provides little information not already contained in the standard reference books, and occasionally, as for The Edinburgh Philosophical Journal, provides incorrect information.

Although accuracy seems to vary with the skills of the volunteer surveying each library, the Union List of Victorian Serials contains much useful information about the holdings of selected libraries, particularly those that are not represented in the Union List of Serials. It can be used to supplement, but will not replace, the standard reference tools. $-S$.S.

\section{GOVERNMENT PUBLICATIONS}

Official Publications of Western Europe. Ed. by Eve Johansson. London, Mansell (dist. in U.S. by H. W. Wilson, N.Y.), 
1984- . V.1- . (In progress) LC 83-22246. ISBN 0-7201-1623-6.

Contents: V.1, Denmark, Finland, France, Ireland, Italy, Luxembourg, Netherlands, Spain, and Turkey. 313p. $\$ 48$.

Useful both to librarians and researchers, this is a handy guide to the publications of the central and local governments of nine western European countries. A second volume is planned to include Austria, Belgium, the Federal Republic of Germany, Greece, Norway, Portugal, Sweden, Switzerland and the United Kingdom; thus, the set will cover the whole of western Europe.

Each chapter deals with one country and in most instances is written by a specialist librarian from that country. A chapter typically begins with an overview of official publications in the country, giving an explanation of the governmental structure and a description of principal publications. The government agencies responsible for publication and distribution of documents are described in the second part of the chapter; a third section is devoted to the means of bibliographic control such as the national bibliography, sales catalogs, and library catalogs. Then follows a directory of relevant national and special-library collections and archives. Local government publications are dealt with in a separate section. Each chapter concludes with a bibliography for further study of public documents, listing items ranging from a government manual to historical studies of government publishing; computerized databases and data retrieval services are listed whenever available. Volume 1 includes indexes by organizations, titles, and subjects. An introductory essay provides a theoretical framework and offers practical advice to acquisitions librarians.

While the Pergamon Press' Guides to Official Publications series offers volumes on certain Western European countries (and includes Vladimir M. Palic's comprehensive but dated Government Publications), this two-volume set with its recent and concise information should be a valuable addition to the library reference collection.-J.S.

\section{BIOGRAPHY}

Banks, Olive. The Biographical Dictionary of British Feminists. Volume One: 1800-1930. N.Y., New York Univ. Pr., 1985. 239p. $\$ 50$. LC 85-3110. ISBN 08147-1078-6.

The compiler's introduction identifies three major nineteenth-century traditions of British feminism represented in this dictionary: equal rights, Owenite, and evangelical feminism. Biographical sketches for 119 male and female feminists are listed in alphabetical order and range in length from several pages to a single column, including brief bibliographies. The Index of Topics lists the biographees under twenty-two subjects, "Abortion" through "Working-class Women and Suffrage."

Articles appear to focus on personal or psychological aspects of the feminists' lives. Exact dates of birth, marriage, or death are rarely given, but many entries contain conjectures about love affairs and family relations. A long paragraph in the entry for Harriet Martineau is devoted to speculation about an early romance, but the title of a major nine-volume work, "published between 1832 and 1834," that was "an instant success not only bringing her financial independence but making her famous," is not given. Entries are sometimes inaccurate: Barbara Bodichon helped found The English Women's Journal, not the Englishwoman's Review, as stated. If Elizabeth Pease Nichol's name had been spelled correctly and not as Nicholl, one would easily find in the DNB that she was married July 6, 1853, not merely "some time in the 1850 's."

Although the introduction maintains that "no other biographical dictionary provides this kind of emphasis, and existing dictionaries tend either to ignore feminists, or in some cases, to seriously misrepresent them,'" The Biographical Dictionary of Modern British Radicals (Suppl. 2AJ39), which now covers the years $1770-1870$, provides longer and more complete entries and bibliographies for most of the feminists active before 1870 , including several not included here. Many British feminists, of course, were active af- 
ter 1870 , and this book is recommended to those libraries unwilling to wait for publication of the next volumes of the Radicals compilation.-S.S.

\section{Contemporaries of Erasmus: A Biographical} Register of the Renaissance and Reformation. Ed. by Peter G. Bietenholz. Toronto, Univ. of Toronto Pr., [1985]-

V.1- . il. (In progress) LC 85-672492. ISBN 0-8020-2507-2.

Contents: V.1, A-E. $\$ 72.50$.

Conceived as a companion to the new edition of the Collected Works of Erasmus (Toronto, 1974- ), this dictionary provides information about "the more than 1900 people mentioned in the correspondence and works of Erasmus who died after 1450 and were thus approximately his contemporaries, if it proved possible to trace and identify them" (preface). Because of Erasmus' prominence and extensive contacts throughout the world of the European Renaissance, the nineteen hundred people included the major political, religious, and learned figures of the day; also among them were many less well known, even obscure, individuals, including friends, relatives, and acquaintances of Erasmus.

Given the wide range of people covered, it is necessary that the amount and type of information provided here varies from entry to entry and is, in some cases, clearly indicated as speculative. For some figures, research uncovered little additional information beyond that gleaned from the references in Erasmus' writings. For others, information drawn from contemporary sources, from diverse historical and biographical sources, and from more recent research, is brought together here. And for yet others-the major rulers, churchmen, and thinkers-who are amply documented elsewhere, the entries in the dictionary concentrate on their connections with Erasmus. Entries are signed and include bibliographical references (when available), notes about existing portraits, and references to appearances in Erasmus' correspondence or works.

This dictionary will be particularly valuable to the student of Erasmus, who will turn to it for information supplementing the annotations in the editions of his works. Moreover, in the absence of a standard biographical work for the period, it is also a unique biographical source for the fifteenth and sixteenth centuries. $-A$. L .

\section{LITERATURE}

Major Modern Dramatists. Rita Stein and Friedhelm Richert, eds. N.Y., Ungar, [1984]- . v.1- . (In progress) LC 78-4310. ISBN 0-8044-3267-8.

Contents: V.1, American, British, Irish, German, Austrian, and Swiss dramatists. 570p. $\$ 75$.

Constituting an addition to the publisher's Library of Literary Criticism series, this volume reprints substantial excerpts from reviews, articles, and books discussing the works of thirty-five European and American late-nineteenth and twentieth-century playwrights from Oscar Wilde and Arthur Schnitzler to Tom Stoppard and Edward Bond. Other European playwrights will be covered in a second volume; Asian and African dramatists will not be included.

Arrangement is by country (or countries, in the case of Germany, Austria, and Switzerland) and playwrights are listed alphabetically within geographic area. The compilers tried "to give an overview of the critical reception of the dramatist from the beginning of his career up to the present time" (introduction), by presenting the excerpts chronologically. There is an index of critics, and a list of the plays mentioned in the excerpts. No biographical or bibliographical sources, other than citations to the original articles, are provided. The compilation is intended for undergraduate and graduate students in modern-drama courses and is a useful summary of major critical opinion.-M.C.

Ward, Robert E. A Bio-bibliography of German-American Writers, 1670-1970. White Plains, N.Y., Kraus [1985]. 377p. \$72. LC 84-17140. ISBN 0-527-94444-0. The author's proposed multivolume set, the Dictionary of German-American Creative Writers, ceased after the publication of volume 1., Bibliographical Handbook (Cleveland, 1978), and Ward has compiled 
the present volume from material collected for his dictionary. GermanAmerican literature is defined as "that body of creative writing composed in the German language by persons of any nationality who reside or have resided in the U.S.A." (introduction). The book offers brief biographical entries of more than three-thousand authors, arranged alphabetically. Each entry includes the titles and dates of "as many literary works by the writer as could be uncovered" (preface), references to anthologies containing an author's works, and "references to important works about the writers and their writings." A bibliography of books and articles discussing German literature is an added feature of the work. The volume should be extremely useful to anyone working in this field, but unfortunately the high price may discourage purchase by libraries without strong collections of the relevant literature.-M.C.

\section{PERFORMING ARTS}

\section{Contemporary Theatre, Film \& Television.}

Ed. by Monica M. O'Donnell. Detroit, Gale, 1984- .V.1- . Annual. V.1:

545p. \$85. ISBN 0-8103-2064-9.

Ostensibly a continuation of Gale's Who's Who in the Theatre (whose entries are cited in the index of the current volume), this work is, according to its subtitle, "a biographical guide featuring performers, directors, writers, producers, designers, managers, choreographers, technicians, composers, executives, dancers, and critics in the United States and Great Britain." That is a tall order, which this first annual volume does not fulfill.

Biographical information is brief, usually only a few lines, and incomplete; some entries have education and personal data, which may or may not include dates. Major film and/or television appearances are listed, often without dates, and almost always without an indication of the part portrayed. Photographs are included, seemingly at random. Addresses, usually of agents, are the only items consistently listed. The emphasis is on current performers, but again inconsistency seems to be the guiding principle. Although the subtitle says that British performers are listed, not even actors familiar to American audiences through "Masterpiece Theater" are included.

This volume may be useful in libraries with a large number of readers wishing to write fan letters to current television personalities; libraries needing a thorough, accurate, and reliable biographical directory for the theater will have to look elsewhere.-M.C.

Bryan, George B. Stage Lives: A Bibliography and Index to Theatrical Biographies in English. Westport, Conn., Greenwood, 1985. 368p. (Bibliographies and indexes in the performing arts, no. 2) $\$ 45$. LC 84-19833. ISBN 0-3132-4577-0.

Bryan, an assistant professor of theater at the University of Vermont, intends this guide to supplement American and British Theatrical Biography (Suppl. 2BG22), Performing Arts Biography Master Index (1982), and Theatre, Film and Television Biographies Master Index (Suppl. 2BG20), and therefore has, with a few exceptions, excluded works already indexed in those volumes.

The work is concerned with collective and individual biographies (including dissertations) in English, of people associated with the stage from the fourth century B.C. to the present day. Approximately twenty-five hundred works are listed. The 154 collective biographies are comprehensively indexed, but unfortunately, individual biographies, which make up the majority of the entries, are indexed only under the main subject. Looking under Gypsy Rose Lee, for instance, the reader finds a reference to Lee's autobiography but not to the autobiographies of her sister, June Havoc, which also have a great deal of information about Lee. Of course, it would be a monumental job to index, even selectively, more than two thousand biographies, but how useful it would have been!-M.C.

\section{SOCIOLOGY}

August, Eugene R. Men's Studies: A Selected and Annotated Interdisciplinary Bibliography. Littleton, Colo., Libraries Un- 
limited, 1985. 215p. \$30. LC 84-28894. ISBN 0-872-87481-8.

Hasn't all of history really been "men's studies"? Not according to August, who believes that ordinary men's social conditions and issues have been underrepresented in past scholarship-that in fact the very concept of masculinity has been limited, distorted, and traditionally applied only to the politically and socially powerful male minority. Furthermore, "men's studies are the logical complement to women's studies and a necessary component of any balanced gender-related scholarship" (introduction). This compilation attempts to provide the balance by listing English-language books in many disciplines that explore the masculinegender role, from the treatment of fathers in divorce and custody cases to male-only service in the military.

A classified arrangement covers areas such as single men, men and women, homosexuality, male midlife transition, literature, minorities, religion, psychology, biology, history, and humor. Entries are numbered and arranged alphabetically by author within sections. The annotations are descriptive, often lengthy, and sometimes evaluative. Cross-references to entries appearing in other sections are included as a reminder of the interdisciplinary nature of many topics (e.g., works on homosexuality appear not only in the section so named but also in the literature, religion, and men's-rights sections). There are author and title indexes. Works included run the gamut from scholarly to popular, from conservative to avantgarde, and the volume should therefore appeal to a wide audience.-D.H.

\section{Black Immigration and Ethnicity in the United}

States: An Annotated Bibliography. Center for Afroamerican and African Studies, Univ. of Michigan. Westport, Conn., Greenwood, [1985]. 170p. (Bibliographies and indexes in Afro-American and African studies, no. 2) $\$ 29.95$. LC 84-12886. ISBN 0-313-24366-2.

The "new" immigration to the United States from the 1960 s to the present has been a topic of considerable interest to social scientists, and their literature searches will be facilitated considerably by this work. Tao Lin Huang, a graduate student and research assistant at the Center for Afroamerican and African Studies, has been primarily responsible for compiling and annotating the references in this bibliography. He has cited 1,049 books, articles, government documents, dissertations, master's theses, and chapter essays published through 1982; about half have descriptive annotations. Arrangement is topical in six main sections: "Bibliographies and Literature Surveys;" "General Works on Immigration and Ethnicity" (most published since 1960); “United States Immigration Legislation and Policies," emphasizing the post-1956 policy developments relating to immigration from Africa and the Caribbean; "Aspects of Black Immigration," including history, demography, economics, education, social services, bilingualism, politics, and literature; "Studies of Individual Groups," including Africans, Caribbeans (general), West Indians, Cubans, Dominicans, Puerto Ricans, and Haitians; and "Select List of Works on Black Immigrants to Canada and Great Britain." There are author and subject indexes.

While the inclusion of Puerto Ricans might be questioned initially, the compiler notes that "although not all of these immigrants are regarded, or regard themselves, as 'Blacks,' a significant proportion of them share varying degrees of African ancestry and have come from areas with significant proportions of Blacks in their population" (introduction). Despite irritating grammatical and typographical errors, this is a useful bibliography.-D.G.

Gilbert, Victor Francis and Darshan Singh Tatla. Immigrants, Minorities, and Race Relations: A Bibliography of Theses and Dissertations Presented at British and Irish Universities, 1900-1981. London, Mansell (dist. in U.S. by H. W. Wilson, N.Y.), 1984. 153p. \$37. LC 83-22185. ISBN 0-7201-1691-0.

As indicated by the subtitle, this is a bibliography of theses and dissertations accepted at universities in Britain on the important topics of immigrants, minorities, 
and race relations, as well as the social conflict that stems therefrom. An introductory essay by Colin Holmes gives a brief summary of immigration in Britain and provides a social context for the work that follows. The bibliography is divided into two sections: "General and Theoretical Studies" and "Regional Studies," both further subdivided by subject and/or country. Each entry includes author, title, degree awarded, the university or college, and the date of the degree. There are no annotations. Studies relating to smaller or tribal communities, Christian minorities in Europe, and studies of social minorities are excluded. There is a detailed subject index and an author index. The compilers indicate that additions and corrections will appear in issues of the journal Immigrants and Minorities.-L.S.

Horak, Stephen M. and Richard Blanke. Eastern European National Minorities, 1919-1980: A Handbook. Littleton, Colo., Libraries Unlimited, 1985.353 p. $\$ 42.50$. LC 84-25004. ISBN 0-87287-416-8.

The authors of this volume plunge bravely into the morass of East European ethnic and national relations to provide an overview and introduction to the literature of these relations, which in the twentieth century have had ramifications far beyond national boundaries. Modeled on Horak's Guide to the Study of the Soviet $\mathrm{Na}$ tionalities: Non-Russian Peoples of the USSR (1982), this handbook consists of an introductory chapter on Eastern European national minorities, chapters on the minorities of each East European country (including one on the Slovene and Croat minorities in Italy since World War II), and a final chapter surveying nationality research centers in eastern European countries, which brings together information not readily available elsewhere. Each chapter is written by a specialist in the field and begins with a historical summary. These essays emphasize statistics (with indications of their fallibilities), political and economic developments, key events, etc., in telling the complex stories of minority-national relations, for which substantial documentation is provided in the footnotes; the copious statistics are drawn from primary as well as secondary sources and are an especially valuable feature of the handbook. Following each essay, except the one on research centers, is a selected, annotated bibliography of books (an occasional article) in both English and foreign languages; the annotations are useful in indicating the particular orientation and value of each source. There is an author and short-title index.

Students and scholars looking for a broad and even-handed survey of the issues and literature or for an identification of major statistics and statistical sources will find this handbook a good place to begin their research. - A.L.

McIntosh, John L. Research on Suicide: A Bibliography. Westport, Conn., Greenwood, 1985. 323p. (Bibliographies and indexes in psychology, no. 2) \$35. LC 84-15706. ISBN 0-313-23992-4.

After just a brief examination of this bibliography, one is struck by the widespread, multidisciplinary and voluminous nature of the research on the mentalhealth problem of suicide. In the compiler's own estimation, the guide is a selected list of basic, useful, English-language materials published between 1970 and 1983, with strongest coverage in the area of suicide survivors. Culled from diverse disciplinesmedicine, psychology, sociology, social work, anthropology, law, philosophy, and religion-writings on suicide demographics, prevention, education, ethics, survivors and "gatekeepers" are well represented. Initial chapters cover bibliographies, definition, theories, and historical background. More esoteric topics include meteorological conditions, mass suicides, suicide notes, psychological autopsies, and suicide in art and literature. Books, book chapters, journal articles, U.S. government documents, and association publications make up the majority of twentythree hundred citations. Annotations are included for important items or for titles that are not self-explanatory; available summaries in other abstracting sources are noted. Recommended items are starred. The table of contents is often unnecessarily detailed and inconsistent, and 
the subject index could use some enrichment, but considering the variety and wealth of the material here, these are minor criticisms.

This librarian has already recommended the bibliography to several researchers interested in suicide among the young, a current and popular interest. The speed with which a new reference book is integrated into the mainstream is an overriding factor in any evaluation of usefulness, and this bibliography promises to pass that test admirably. - L. B.

\section{HISTORY \& AREA STUDIES}

Collins Australian Encyclopedia. John Shaw, ed. Sydney, Collins in assoc. with D. Bateman (dist. in U.S. by Hall, Boston), [1984]. 848p. il. \$49.95. LC 84-156336. ISBN 0-00-217315-8.

For libraries in which purchase of the twelve-volume Australian Encyclopedia (4th ed. Sydney, Grolier Soc. of Australia, 1983) does not seem justified, this volume offers an attractive alternative. It presents "broad, yet representative coverage of topics in almost every field of knowledge" (preface) as they relate to Australia, and it is particularly strong in natural history. Articles are unsigned, but a list of contributing authors is included; suggestions for further reading are appended to many articles. Sources of statistical tables are noted; population figures are from the 1981 census. The many biographical entries include living persons, and there are entries for urban centers with populations of more than two thousand; some smaller places of unusual interest also are included. Black-and-white illustrations appear on nearly every page, and there are numerous color plates. Words in small capitals within articles signal see also references; there are cross-references at the end of some articles; see references from unused headings appear throughout the text. In addition, there is a subject index that groups the encyclopedia entries under fairly broad headings; additional cross-references would have been useful in this index. A number of useful appendixes complete this interesting volume.E.S.
Dictionary of Modern Italian History. Frank J. Coppa, ed. in chief. Westport, Conn., Greenwood, [1985]. 496p. \$55. LC 84-6704. ISBN 0-313-22983-X.

In order to cover "the chief events, personalities, institutions, systems, problems of Italy from the eighteenth century" (preface), Coppa and his contributors present short articles (one hundred to nine hundred words) on "the major Italian political, economic, cultural, social, and religious issues ... [ [with] special focus on the issues of industrialization, banking, regionalism, and political theory, "and include entries for newspapers, education, and the Enlightenment, among other topics. Each article is signed with the initials of the contributor and many of the longer entries include at least one bibliographical reference. The articles seem well written and the topics carefully chosen. Of course one could always quibble about selection and treatment, but there does appear to be a judicious mix of novelists, composers, political leaders, parties, historical periods, etc. There is a useful appendix with chronological lists of ministers, kings, presidents, and popes, and a very good subject index enhances the dictionary. $-E . M$.

Franklin D. Roosevelt, His Life and Times: An Encyclopedic View. Ed. by Otis L. Graham, Jr., and Meghan Robinson Wander. Boston, Hall. [1985]. 483p. il. \$48. LC 84-25149. ISBN 0-8161-8667-7.

The first in the publisher's planned series of presidential encyclopedias, this publication is similar in presentation to Mark E. Neely's Abraham Lincoln Encyclopedia (N.Y., McGraw-Hill, 1982). The Roosevelt volume is, however, a collaborative work by a number of scholars and graduate students. According to the editors the aim was "to create for the reader a sense of Roosevelt's era, his political thought, and the problems that faced him as both a national and an international leader" (introduction). Signed articles on 321 topics, covering "ideologies and issues, legislation, federal agencies, political parties, interest groups, aspects of Franklin D. Roosevelt's personal life, and people of importance to him" are the prin- 
cipal content of the encyclopedia. Bibliographies, which follow the articles, include archival and unpublished material, together with brief commentaries on published works. A number of quotations from Roosevelt's speeches and writings are incorporated in the articles, and there is a generous number of photographs (which are fully indexed). Crossreferences to related topics are often given at the end of an article.

In view of the vast amount of material available on F. D. R., this work should serve as a starting point for many research topics, but the editors' aim of giving the reader a feel for the Roosevelt era would probably be met better by a well-written biography. (Alternatively, a classified subject or chronological arrangement rather than this alphabetical sequence of topics might have conveyed better the drama of the era.) This is an agreeable work to browse, and it offers good bibliographies, but the reader should not expect incisive comments on controversial issues or penetrating analyses of Roosevelt's life and times.-J.S.

Historical Atlas of Africa. J. F. Ade Ajayi and Michael Crowder, gen. eds. Cambridge and N.Y., Cambridge Univ. Pr., 1985. 172p. map. \$75. LC 83-675975. ISBN 0-521-25353-5.

Fage and Verity's Atlas of African History (Guide DD41) was first published in 1959 and represented a pioneering effort in mapping Africa's history. More than ten years ago the general editors of this new atlas decided that definite advances in the way the African past is perceived, as well as the development of sophisticated cartographic techniques, justified a more ambitious work. Their determination to see this project to fruition will earn them the longlasting gratitude of all Africanists. The strictly historical development of different regions is interpreted in a dynamic visual style. In addition, thematic maps to illustrate geographic, climatic, demographic, linguistic, agricultural, political, economic, educational, and religious trends make full use of proportional symbols, density shading, numeric data, graphs, and diagrams. A page of excellent, de- scriptive text, photographs, and drawings complements each of the seventy-two full-color plates. The credentials of the production are impeccable: the contributors are all well-known area specialists and historians. The spelling of proper names and places has been standardized, and a detailed index concludes this instructive and beautiful achievement.L.B.

Holmes, Lowell Don. Samoan Island Bibliography. Wichita, Kans., Poly Concepts, 1984. 329p. \$85. LC 83-062482. ISBN 0-915203-00-6.

Everything that could be found on Samoa is cited in this bibliography: books, chapters, and page references in books, periodical articles, newspaper articles (most from the New York Times and the Samoan Reporter), theses (both master's and Ph.D., mainly American), films, manuscripts and archives, government documents, and international-organization publications. Items are listed alphabetically within forty-four subject divisions, some as broad as socio-cultural anthropology, others as narrow as cruises or philately. Works of all periods are included, as are all applicable languages, though most are English-language materials. There are some curiosities: why list only the 1968 U.N. Demographic Yearbook or the 1969 U. N. Statistical Yearbook with no indication that these are continuing series? Under "Politics, Government and Administration" all U.S. government documents, whether published or in the National Archives, are listed chronologically regardless of issuing agency. Wouldn't researchers find it easier to have all congressional publications or all State Department items grouped together rather than scattered through a list covering thirteen pages?

The sorrow, however, is that there is no index-neither author nor subject. So much care and effort evidently went into compiling this bibliography that it's a shame a little more energy wasn't expended to make a superb reference source. Since the information is on computer tape, perhaps a program could be developed for producing an index volume. As it now stands, a researcher with 
patience will find this an exhaustive bibliography. The price, of course, is unfortunate. - E.M.

The Holocaust: An Annotated Bibliography and Resource Guide. Ed. by David N. Szonyi. [Hoboken, N.J.] KTAV Publishing House for the National Jewish Resource Center, N.Y., 1985. 396p. \$29.50. LC 84-26191. ISBN 0-88125-057-0.

A bibliography with an unusual twist, this is a useful resource for locating materials and sources of information "related to learning about or teaching the Holocaust" (preface). The work grew out of the many information requests received by organizations such as ZACHOR, the Holocaust Resource Center. Section 1 comprises the bibliography and is divided into three sections: "Scholarship, Memoirs, and Other Nonfiction of the Holocaust," "Literature of the Holocaust: A Selected Bibliography," and "Bibliographies on the Holocaust for Young People." Each section is further subdivided by topic (e.g., "Roots of the Holocaust" or "Fiction"). The entries include complete bibliographic citation and a brief (usually one or two lines) annotation for the book or article cited. Emphasis is on recently published (primarily 1960 and later) items in English, although earlier works are included when particularly useful. The remaining twelve sections make up the resource guide. It is this part of the work that may prove to be the most valuable, as it is the resource materials that are most difficult to find. Each section is devoted to a specific type of resource, with annotations and addresses for further information. Some of the sections of particular interest are those on Holocaust-education centers, traveling exhibits, the development of curricula for teaching about the Holocaust, and a list of Holocaust-survivor support groups. A subject and name index would have improved the usefulness of this volume. - L.S.

The Presidents: A Reference History. Henry

F. Graff, ed. N.Y., Scribner, 1984. 700p.

\$60. LC 83-20225. ISBN 0-684-17607-6.

More than a series of biographical sketches of the presidents, this volume of- fers a chronological history of the presidency presented in the form of interpretive essays on the individual men who held the office, the events and developments of each administration, and their significance in the course of American history. Thirty-five professional historians and political scientists, "each a specialist on the president of whom he writes" (introduction), have contributed essays on chief executives from Washington through Carter (Harrison and Tyler, Taylor and Fillmore, and Garfield and Arthur are treated in pairs). Essays follow no rigid pattern, but typically provide an account of early life and prepresidency years before concentrating on the time in office. Boldface headings in most of the essays highlight major issues and events of a career-a boon to the reference librarian in search of a specific fact. A bibliography is appended to each essay, and evaluative statements are incorporated therein; some give references to manuscript sources or to editions of writings of the president. An index adds to the reference value of the work.-E.S.

Writings on American History, 1962-73: A Subject Bibliography of Books and Monographs. Based on a compilation by James R. Masterson. Wash., Amer. Historical Assn.; White Plains, N.Y., Kraus, 1985. $10 \mathrm{v}$. $\$ 1,300$. LC $82-49027$. ISBN 0-527-98268-7.

Intended as a companion to the similarly titled bibliography of periodical articles from the same period (Suppl. DB11), this set is meant to close the gap between the 1902-1961 series of Writings on American History (Guide DB31) and the new series of that title, which began in 1974 (Suppl. DB12). This is a bibliography of more than fifty thousand books and monographs "on the history, the geography, and the political, social, and economic aspects of the United States, its people, its government, and its institutions" (introduction). Citations are derived from Library of Congress catalog cards and include classification numbers and descriptive or contents notes as applicable. Entries are arranged in five main categories: (1) History and historians 
(which includes subdivisions for bibliography, historiography, libraries and archives, etc.); (2) Chronological classification (a general, multiperiod listing followed by twelve historical periods); (3) Subject classification (with subdivisions for cultural and intellectual history, history of science and technology, transportation history, etc.); (4) Geographical classification (New England through Pacific, subdivided by state, plus a section for territories and dependencies); (5) Biography. An index of authors, editors and compilers, and one of personal names as subjects complete the set.

Admirable as the intent of this publication may be, the result is disappointing. As in the companion set for periodical articles, the topical categories are too broad for effective subject searching, and there is no detailed subject index beyond that for personal names. Serendipity aside, the researcher might more profitably consult the three relevant cumulations of the $\mathrm{Li}$ brary of Congress subject catalog (Guide AA99) under a precise heading such as "U.S.-History-Civil War-Causes" rather than scan the forty-three pages of "Civil War and Reconstruction" entries in this compilation.-E.S.

\section{HISTORY OF MEDICINE}

McGrew, Roderick E. Encyclopedia of Medical History. With the collaboration of Margaret P. McGrew. N.Y., McGrawHill, [1985]. 400p. \$34.95. LC 84-17158. ISBN 0-07-045087-0.

McGrew intends his dictionary of more than one hundred essays on medical history to be both for students of the history of medicine and for the general reader. A historian himself, he writes clearly and without jargon, covering a wide range of topics from abortion and acupuncture to vitamins and yellow fever. For each entry the author gives a definition, then a chronological account of the history of the topic-including symptoms, characteristics, effects, attitudes, developments in treatment, alternate names-and ends with a short list of suggested readings. A topic must have a history in order to be included: thus, no AIDS, and for some of the more recent innovations there is no coverage (e.g., the Lamaze method of childbirth). There are no separate biographical entries; however, some biographical notes appear in the articles when appropriate. The detailed subject index is very workable; for the more important people whose work is discussed dates are given in the index entry.

While this compendium is particularly well suited to the needs of the generalist, it will also be useful to the medical student and the scholar because of the way the major facts pertinent to each topic are assembled and presented, and for the brief bibliographies for further reading.-E.M.

\section{NEW EDITIONS, SUPPLEMENTS, ETC.}

For the second edition of the Harper Dictionary of Contemporary Usage, by William and Mary Morris (N.Y., Harper \& Row, 1985. 641p. \$22.50), the panel of "distinguished consultants on usage" was increased from 136 to 166 persons, mainly authors and editors. As in the 1975 edition (Suppl. AD14), panel members' opinions on many controversial usages are expressed in percentages of the total response, with individual comments frequently appended.

British Literary Magazines: The Victorian and Edwardian Age, 1837-1913 (Westport, Conn., Greenwood, 1984.560p. \$75) is the third volume in the series of reference guides to literary journals, edited by Alvin Sullivan. It offers essay profiles on ninety magazines of the period (including titles such as The Cornhill, The Granta, and The Nineteenth Century), and lists more than two hundred other titles in the appendixes.

First published in 1981, Stephen Richard's Directory of British Official Publications: A Guide to Sources is now available in an enlarged second edition (London and N.Y., Mansell, 1984. 431p. \$60). Because an increased number of publications "are being issued by government departments and other official organisations not publishing through HMSO," the guide serves as a useful tool for "identifying publications sources, publications listings, and 
giving contact addresses, and guiding the user around British official publishing" (introduction). There are nearly thirteen hundred entries in this edition.

John W. Raimo's Biographical Directory of the Governors of the United States, 1978-1983 (Westport, Conn., Meckler, 1985. 352p. $\$ 45)$ is a "sequel" to Sobel and Raimo's compilation, which covered the 1789-1978 period (Suppl. AJ15). It provides biographies of eighty-seven persons who held office between January 1978 and January 1983 and includes the work of seven contributing scholars.

Subtitled "A Biographical Encyclopedia of 5,000 Leading Personalities in the Soviet Union," Borys Lewytzkyj's Who's Who in the Soviet Union (Mun̈chen, Saur, 1984, 428p. DM298) serves to update information on Soviet figures included in the editor's Who's Who in the Socialist Countries (1978; Suppl. AJ8). Following the alphabetical arrangement of biographies, there is an extensive index section that lists, by individual republic and area of activity, the names of party, state, tradeunion leaders, and office holders, together with lists of authors, artists, and scientists.

Although Margaret Drabble's revision of The Oxford Companion to English Literature (5th ed. Oxford and N.Y., Oxford Univ. Pr., 1985. 1155p. \$35) has received widespread attention elsewhere, it merits mention here. While it retains many of the characteristics of Sir Paul Harvey's original compilation (Guide BD412), there has been considerable reworking of existing articles (virtually all show at least some slight revision) and much pruning of tangential matter, in order to accommodate new articles; new entries for many writers born before 1940 have been added. The appendixes, on "Censorship and the Law of the Press," "Notes on the History of English Copyright," and "The Calendar," have been retained.

With the appearance of the index volume (1985. 288p. \$220), the sixteenvolume set of Variety Film Reviews, 1907-1980 (N.Y., Garland, 1983-85) is now complete. Arranged by date of publication, the set reproduces all film reviews printed in Variety through June 1927 and all reviews of feature-length films appearing after that date. Indexing is by film title only, with cross-references from English titles of foreign films.

Gail Ann Schlachter's Directory of Financial Aids for Women, 1985-86 (Santa Barbara, Calif., ABC-Clio, 1985. 380p. \$35) represents the third edition of that title (see Suppl. CC196), with an increase of about 30 percent in the size of the volume. Programs no longer in existence or that have broadened their scope to include men have been dropped, and descriptions of continuing programs have been updated to reflect current policies and operations.

Paul G. Partington has published a supplement (Whittier, Calif., Author, 1985. 20p. \$5) to his W. E. B. DuBois: A Bibliography of His Published Writings (1977; Suppl. CC135). It lists numerous manuscript articles as well as additions to the bibliography of published works.

First published in 1962, The American Political Dictionary by Jack C. Plano and Milton Greenberg (Guide CJ48) has now appeared in a seventh edition (N.Y., Holt, 1985. 606p. \$15.95). Numerous articles have been revised and updated; entries for new terms have been added; and the text of the United States Constitution is now included as an appendix.

Bill Wedertz's Dictionary of Naval Abbreviations is now available in a third edition (Annapolis, Md., Naval Inst. Pr., 1984. 329p. \$15.95). An attempt has been made to eliminate obsolete abbreviations found in the earlier editions (Guide CJ275; Suppl. CJ155) and make the work as up-to-date as possible.

Following the precedent of earlier revisions (Guide DA5), the fourth edition of The Modern Researcher by Jacques Barzun and Henry F. Graff (San Diego, Calif., HBJ, 1985. 450p. \$24.95) "presents new examples from recent events, titles of new reference books, new uses of old methods, and old uses of new devices such as computers, word processors, and data banks" (p.xi). Once again the work is available in paperback (\$13.95) as well as hardcover.

The long-awaited third volume of Warren F. Kuehl's Dissertations in History 
(Santa Barbara, Calif., ABC-Clio, 1985. $466 \mathrm{p} . \$ 58.50$ ) is a supplement covering the period from 1970 to June 1980 . Instead of the alphabetical author listing of the previous volumes (Guide DA26), a classified arrangement by country and period, similar to that used in the American Historical Association's Recently Published Articles, is employed. There are author and detailed subject indexes for the 9,905 entries.

A. G. S. Enser's 1977 World War II bibliography (Suppl. DA43) listed English language books from the 1939-74 period. His new compilation, A Subject Bibliography of the Second World War: Books in English, 1975-1983 (Aldershot, Eng. \& Brookfield, Vt., Gower, 1985. 225p. \$40) brings the record more nearly up-to-date and in- cludes citations to many publications whose authors had access to documents of 1944 and later which became available for inspection in the Public Record Office under the thirty-year rule.

The tenth edition of the DahlmannWaitz Quellenkunde der deutschen Geschichte; Bibliographie der Quellen und der Literatur zur deutschen Geschichte (Guide $\mathrm{DC} 121)$ has been appearing in parts since 1965. Now that the first two volumes are complete, a "Register zu Band 1 und 2" has been issued (Stuttgart, Hiersemann, 1985. 496p.). It offers indexes of authors, editors, and corporate authors, of personal names in titles, and of place names in titles. - E.S. 


\section{ACQUISITION PERSPECTIVES}

2. Book House guarantees to order each book you request, with regular claiming to publishers. From major publishers on open account to the most obscure press requiring prepayment and offering no discount, our persistence and experience enables us to deliver every available title.

There is no substitute for complete delivery.

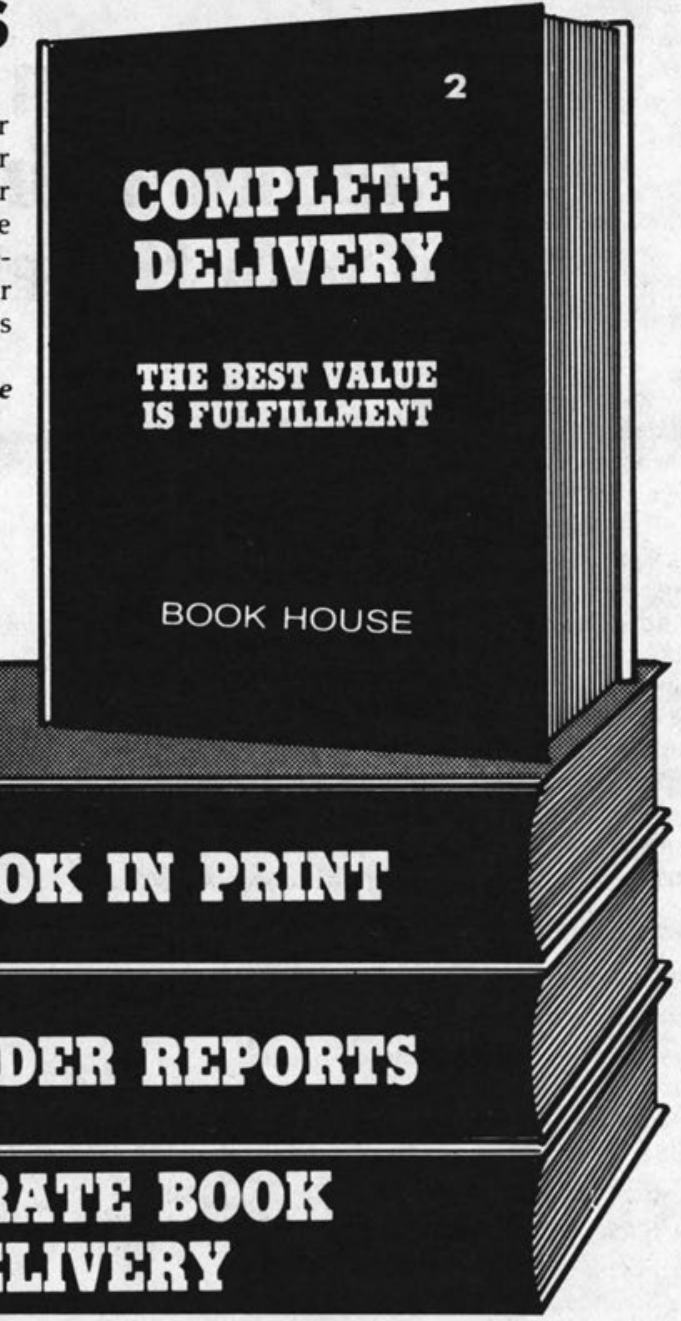

3 OPHN ORDHR RPPORTS

4 ACCURATE BOOK DHWVHR?

\section{CALL TOLL-FREE TODAY 1-800-248-1146}

In Canada \& Michigan CALL COLLECT (517) 849-2117

OCLC Vendor No. 17397

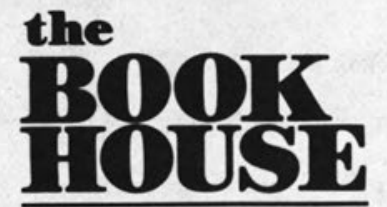

JOBBERS SERVING LUBRARIES WITH ANY BOOK IN PRINT SINCE 1962 208 WEST CHICAGO STREET JONESVILLE, MICHIGAN 49250 


\section{Put more than 850,000 author addresses at your fingertips...}

Now there's a valuable new source for the addresses of authors publishing in the sciences, social sciences, and the arts \& humanities: the Current Contents ${ }^{\circledR}$ Address Directory.

The Current Contents Address Directory can provide you with all the author addresses your patrons need in a wide variety of subject areas. Depending upon the disciplines your library serves, choose one or both editions of the Current Contents Address Directory: Science \& Technology, and Social Sciences/ Arts \& Humanities.

The Current Contents Address Directory has three indexes for fast, easy searching. The author index lists names and addresses of authors and coauthors, plus brief descriptions

Please send me the following editions of the Current Contents ${ }^{\star}$ Address Directory-1984 edition, covering authors who published during 1984:

Science \& Technology. . . . . . . . . . \$345

Social Sciences/Arts \& Humanities . \$195

Science \& Technology and Social

Sciences/Arts \& Humanities . . . . . . . \$540

$\$ 490$

NAMETITLE

ORGANIZATIONDEPT.

ADDRESS

\begin{tabular}{lll}
\hline CITY STATEPPOVINCE & COUNTRY
\end{tabular}

ZIPIPOSTAL CODE PHONE of their publications. The organization index provides access to author addresses by institutional affiliation, and the geographical index provides access by institutional location.

Order your copies of the Current Contents Address Directory now, and take advantage of these special prices: the Current Contents Address Directory-Science \& Technology is $\$ 345$; the Current Contents Address Directory-Social Sciences/Arts \& Humanities is $\$ 195$. Order both directories for just $\$ 490$ - a savings of $\$ 50$ off the combined price!

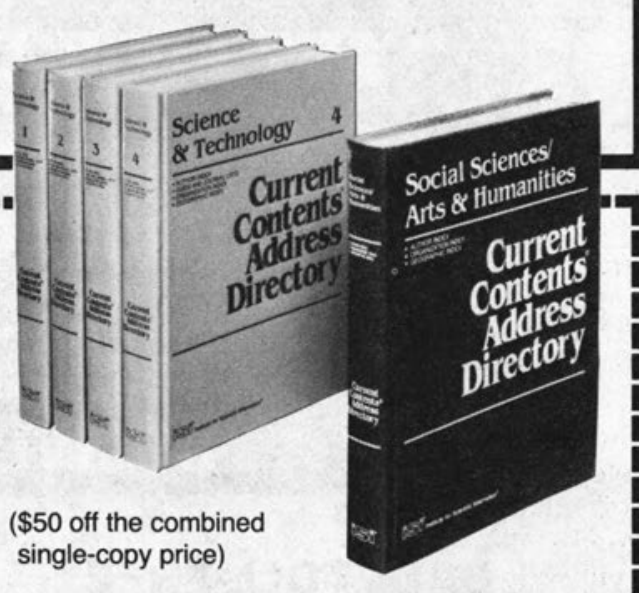

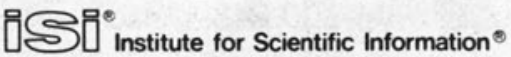
Fulfillment Services Department

3501 Market Street, Philadelphia, PA 19104 U.S.A.

Telephone: (215) 386-0100, Cable: SCINFO, Telex: $84-5305$ European Office

132 High Street, Uxbridge, Middlesex UB8 1DP, United Kingdom Telephone: $44-895-70016$, Telex : 933693 UKISI

Orges is! 101-4001 